\title{
Synthesis and Biological Evaluation of Some Novel 1,8-Naphthyridine Derivatives
}

\author{
Sraa Abu-Melha* \\ ${ }^{*}$ Department of Chemistry, Faculty of Science of Girls, King Khaled University, Abha, \\ Saudi Arabia \\ *Corresponding author: E-mail: sraa201313@yahoo.com \\ Tel: +966504757797
}

Received: 06-06-2017

\begin{abstract}
A series of substituted 1,8-naphthyridine derivatives was synthesized to be used as cytotoxic and antioxidant agents by applying 1,4-dihydro-4-oxo-1,8-naphthyridine-3-carbohydrazide (1) as the starting material. Compound 1 was reacted with different reagents to afford the corresponding 3-heterarylcarbonyl-1,8-naphthyridine derivatives 3-19 which were tested for their in vitro cytotoxicity against Ehrlich Ascites Carcinoma, and antioxidant activity. Compound 15 showed the best cytotoxicity and antioxidant activity.
\end{abstract}

Keywords: 1,8-naphthyridine; quinazolone; pyrazole; cytotoxicity; antioxidant activity

\section{Introduction}

Studies on the synthesis of 1,8-naphthyridines have served as a fertile field of research in the perusal for antibacterial agents. ${ }^{1-3}$ Nalidixic acid (1-ethyl-3-carboxy-7methyl-1,8-naphthyridine-4-one) has been found to be effective particularly against gram negative bacteria found in chronic urinary tract infections. ${ }^{4}$ 1,8-Naphthyridine derivatives were found to display moderate cytotoxic activity against murine p388 leukemia, when changes were carried out at $\mathrm{N}-1$ and $\mathrm{N}-7$ positions. ${ }^{5,6}$ It has been reported that C-3 carboxamide derivatives with a spacer have shown good cytotoxicity along with anti-inflammatory activity. ${ }^{7}$

Pharmacologically, pyrazole and its derivatives represent one of the most important classes of organic heterocyclic compounds, possessing anti-bacterial, anti-fungal, ${ }^{8}$ herbicidal ${ }^{9}$ and anti-viral activities. ${ }^{10}$

Moreover, the chemistry of carbohydrazoles has gained increased interest in both synthetic organic chemistry and biological fields and has considerable value in many useful applications, such as the assessment process of the three dimensional ultra structure examination techniques of interphase nuclei and tissues, besides their therapeutic importance. ${ }^{11}$

\section{Experimental}

\section{1. Materials and Methods}

\section{1. 1. Chemicals and Reagents}

All the chemicals and solvents used in this study were obtained from Merck (Germany) and Sigma-Aldrich chemical company (Germany).

\section{1. 2. Instruments}

All melting points were recorded on Gallenkamp electric melting point apparatus and are uncorrected. The IR spectra $v \mathrm{~cm}^{-1}(\mathrm{KBr})$ were recorded on Perkin-Elmer Infrared Spectrophotometer Model 157, Grating. The ${ }^{1} \mathrm{H}$ and ${ }^{13} \mathrm{C}$ NMR spectra were run on Varian Spectrophotometer at $400 \mathrm{MHz}$ and $100 \mathrm{MHz}$ using TMS as the internal reference and DMSO- $d_{6}$ as the solvent. Chemical shifts $(\delta)$ are given in $\mathrm{ppm}$. The mass spectra (EI) were recorded on $70 \mathrm{eV}$ with Kratos MS equipment and/or Varian MAT 311 A Spectrometer at Cairo University, Giza, Egypt, and at Assuit University Central Laboratory. Elemental analyses $(\mathrm{C}, \mathrm{H}$, and $\mathrm{N})$ were carried out at the Microanalytical Center of Cairo University, Giza, Egypt (automatic analyzer CHNS, Vario ELIII-elementar, Ger- 
many). The results were found to be in good agreement with the calculated values.

\section{2. Synthesis}

\section{2. 1. Synthesis of 1,4-Dihydro-N-(2-methyl- 4-oxoquinazolin-3(4H)-yl)-4-oxo-1,8- naphthyridine-3-carboxamide (3)}

A mixture of separated or freshly prepared benzoxazine $2^{12}(1.16 \mathrm{~g}, 10 \mathrm{mmol})$ and 4-oxo-1,4-dihydro-1,8-naphthyridine-3-carbohydrazide (1) (2.04 g, 10 $\mathrm{mmol})$ in ethanol $(25 \mathrm{~mL})$ containing glacial acetic acid (5 $\mathrm{mL}$ ) was refluxed for $4 \mathrm{~h}$. The formed precipitate was filtered off, dried and recrystallized from ethanol to give compound 3. Yield $63 \%$; White crystal; m.p. $289^{\circ} \mathrm{C}$; IR (KBr): $v_{\max } 3230-3238(\mathrm{br}, 2 \mathrm{NH}), 1668,1671(\mathrm{C}=\mathrm{O}$, amidic), $1614(\alpha, \beta$-unsaturated $\mathrm{C}=\mathrm{O}),{ }^{13} 1569(\mathrm{C}=\mathrm{N}) \mathrm{cm}^{-1} ;{ }^{1} \mathrm{H}$ NMR (DMSO- $\left.d_{6}\right) \delta 1.93\left(\mathrm{~s}, 3 \mathrm{H}, \mathrm{CH}_{3}\right), 7.62-8.24(\mathrm{~m}, 7 \mathrm{H}$, Ar-H), 9.01 (s, 1H, $\mathrm{C}_{2}-\mathrm{H}$ of naphthyridine ring), 9.21 (s, $1 \mathrm{H}, \mathrm{NH}), 10.66(\mathrm{~s}, 1 \mathrm{H}, \mathrm{NH}) ;{ }^{13} \mathrm{C}$ NMR (DMSO- $\left.d_{6}\right) \delta 21.6$, $113.8,114,121.1,122.3,123.9,126.6,127.8,134.2,138.1$, 141.7, 148.2, 151.4, 152.6, 162.1, 164.4, 165.9, 176.8; MS (EI, $70 \mathrm{eV}) \mathrm{m} / z$ (\%) $347\left(\mathrm{M}^{+}, 4.03\right), 272$ (6.05), 259 (5.26), 230 (10.31), 173 (61.90), 138 (8.82), 123 (8.09), 104 (62.02), 89 (9.44), 77 (100), 75 (17.03), 63 (24.58), 51 (67.43), 49 (13.12); Anal. calcd. for $\mathrm{C}_{18} \mathrm{H}_{13} \mathrm{~N}_{5} \mathrm{O}_{3}$ (347.33): C, 62.24; H, 3.77; N, 20.16. Found: C, 62.36; H, 3.59; N, 20.31 .

\section{2. 2. Synthesis of Ethyl 3-(2-(4-Oxo-1,4-dihydro- 1,8-naphthyridine-3-carbonyl)hydrazono) butanoate (4)}

A mixture of compound $1(2.04 \mathrm{~g}, 10 \mathrm{mmol})$ and ethyl acetoacetate $(1.3 \mathrm{~g}, 10 \mathrm{mmol})$ was refluxed in ethanol $(25 \mathrm{~mL})$ containing drops of glacial acetic acid for $2 \mathrm{~h}$. The reaction mixture was cooled to room temperature. The solid product that formed was filtered off, dried, and recrystallized from ethanol to give compound 4. Yield 95\%; pale yellow crystal; m.p. $209^{\circ} \mathrm{C}$; IR (KBr): $v_{\max } 3237-3255$ (br, NH), 1724 ( $\mathrm{C}=\mathrm{O}$ of ester group), 1689 ( $\mathrm{C}=\mathrm{O}$, amidic), $1625(\alpha, \beta$-unsaturated $\mathrm{C}=\mathrm{O}), 1567(\mathrm{C}=\mathrm{N}) \mathrm{cm}^{-1} ;{ }^{1} \mathrm{H}$ NMR $\left(\mathrm{DMSO}-d_{6}\right) \delta 0.91\left(\mathrm{~s}, 3 \mathrm{H}, \mathrm{CH}_{3}\right), 1.38\left(\mathrm{t}, 3 \mathrm{H}, \mathrm{CH}_{3}\right), 2.35(\mathrm{~s}$, $\left.2 \mathrm{H}, \mathrm{CH}_{2}\right), 4.25\left(\mathrm{q}, 2 \mathrm{H}, \mathrm{CH}_{2}\right), 7.60-8.24(\mathrm{~m}, 3 \mathrm{H}, \mathrm{CH}-$ pyridine ring), 8.61 (s, $1 \mathrm{H}, \mathrm{C}_{2}-\mathrm{H}$ of naphthyridine ring), 10.81 (s, $1 \mathrm{H}, \mathrm{NH}), 11.01(\mathrm{~s}, 1 \mathrm{H}, \mathrm{NH}) ; \mathrm{MS}(\mathrm{EI}, 70 \mathrm{eV}) \mathrm{m} / z(\%)$ $316\left(\mathrm{M}^{+}, 17.5\right), 271(2.8), 245(0.2), 229$ (69.0), $204(0.5)$, 202 (1.4), 189 (1.6), 173 (100), 145 (2.3), 104 (12.3), 76 (10.6); Anal. calcd. for $\mathrm{C}_{15} \mathrm{H}_{16} \mathrm{~N}_{4} \mathrm{O}_{4}(316.31)$ : C, 56.96; $\mathrm{H}$, 5.10; N, 17.71. Found: C, 56.96; H, 5.12; N, 17.93.

\section{2. 3. Synthesis of 3-(3-Methyl-5-oxo-4,5-dihydro- 1H-pyrazole-1-carbonyl)-1,8-naphthyridin- 4(1H)-one (5)}

Compound 4 ( $3.16 \mathrm{~g}, 10 \mathrm{mmol})$ was refluxed in ethanol $(30 \mathrm{~mL})$ containing sodium metal $(0.23 \mathrm{~g}, 10 \mathrm{mmol})$ for $5 \mathrm{~h}$, cooled to room temperature, and poured into ice cold water. The separated solid was filtered, dried, and recrystallized from ethanol to give 5. Yield 59\%; pale brown powder; m.p. $>300{ }^{\circ} \mathrm{C}$; IR $(\mathrm{KBr}): v_{\max } 3134(\mathrm{NH}), 1669$, $1674(\mathrm{C}=\mathrm{O}$, amidic), $1636(\alpha, \beta$-unsaturated $\mathrm{C}=\mathrm{O}), 1606$ $(\mathrm{C}=\mathrm{N}) \mathrm{cm}^{-1} ;{ }^{1} \mathrm{H}$ NMR (DMSO- $\left.d_{6}\right) \delta 1.22\left(\mathrm{~s}, 3 \mathrm{H}, \mathrm{CH}_{3}\right)$, 2.07 (s, $\left.2 \mathrm{H}, \mathrm{CH}_{2}\right), 6.76-8.63(\mathrm{~m}, 3 \mathrm{H}, \mathrm{CH}$-pyridine ring), $8.41\left(\mathrm{~s}, 1 \mathrm{H}, \mathrm{C}_{2}-\mathrm{H}\right.$ of naphthyridine ring), $9.83(\mathrm{~s}, 1 \mathrm{H}$, $\mathrm{NH}) ;{ }^{13} \mathrm{C}$ NMR (DMSO- $d_{6}$ ) $\delta 26.5,43.2,113.8,114,122.3$, 138, 141.7, 151.4, 152.6, 158.2, 161.4, 167.1, 176.8; MS (EI, $70 \mathrm{eV}) \mathrm{m} / z(\%) 270\left(\mathrm{M}^{+}, 0.26\right), 173(0.4), 168(2.07)$, 125 (0.64), 111 (8.76), 97 (0.63), 84 (13.67), 77 (1.54), 68 (4.23), 52 (100); Anal. calcd. for $\mathrm{C}_{13} \mathrm{H}_{10} \mathrm{~N}_{4} \mathrm{O}_{3}$ (270.24): C, 57.78; H, 3.73; N, 20.73. Found: C, 57.77; H, 3.64; N, 20.71 .

\section{2. 4. Synthesis of 4-Oxo-N'-(4-oxopentan-2- ylidene)-1,4-dihydro-1,8-naphthyridine-3- carbohydrazide (6)}

A mixture of 1 ( $2.04 \mathrm{~g}, 10 \mathrm{mmol})$ and acetylacetone $(1.0 \mathrm{~g}, 10 \mathrm{mmol})$ was refluxed in ethanol $(25 \mathrm{~mL})$ containing a few drops of glacial acetic acid for $2 \mathrm{~h}$. The reaction mixture was left to cool, and then poured into ice cold water. The solid product was filtered off, dried, and recrystallized from ethanol to give compound 6 . Yield $41 \%$; dark yellow powder; m.p. $>300^{\circ} \mathrm{C}$; IR $(\mathrm{KBr}): v_{\max } 3251(\mathrm{br}, \mathrm{NH})$, $1743(\mathrm{C}=\mathrm{O}$, ketonic), $1681(\mathrm{C}=\mathrm{O}$, amidic), $1627(\alpha, \beta$-unsaturated $\mathrm{C}=\mathrm{O}), 1569(\mathrm{C}=\mathrm{N}), 1548(\mathrm{C}=\mathrm{C}) \mathrm{cm}^{-1} ;{ }^{1} \mathrm{H}$ NMR $\left(\mathrm{DMSO}-d_{6}\right) \delta 1.20\left(\mathrm{~s}, 3 \mathrm{H}, \mathrm{CH}_{3}\right), 2.11\left(\mathrm{~s}, 3 \mathrm{H}, \mathrm{CH}_{3}\right), 2.54(\mathrm{~s}$, $\left.2 \mathrm{H}, \mathrm{CH}_{2}\right), 8.48\left(\mathrm{~s}, 1 \mathrm{H}, \mathrm{C}_{2}-\mathrm{H}\right.$ of naphthyridine ring), 7.62$8.76(\mathrm{~m}, 3 \mathrm{H}, \mathrm{CH}$-pyridine ring), $10.49(\mathrm{~s}, 1 \mathrm{H}, \mathrm{NH}), 11.20$ (s, 1H, NH); MS (EI, $70 \mathrm{eV}) \mathrm{m} / z(\%) 286\left(\mathrm{M}^{+}, 11.0\right), 285$ (41.57), 148 (38.57), 134 (53.00), 117 (36.02), 77 (78.89), 64 (88.82), 50 (100), 49 (63.92), 45 (64.72); Anal. calcd. for $\mathrm{C}_{14} \mathrm{H}_{14} \mathrm{~N}_{4} \mathrm{O}_{3}$ (286.29): C, 58.73; H, 4.93; N, 19.57. Found: C, $58.72 ; \mathrm{H}, 4.83 ; \mathrm{N}, 19.69$.

\section{2. 5. Synthesis of 3-(3,5-Dimethyl-1H-pyrazole- 1-carbonyl)-1,8-naphthyridin-4(1H)-one (7)}

A mixture of $6(2.86 \mathrm{~g}, 10 \mathrm{mmol})$ and acetylacetone $(1.0 \mathrm{~g}, 10 \mathrm{mmol})$ was refluxed in ethanol $(30 \mathrm{~mL})$ containing sodium metal $(0.23 \mathrm{~g}, 10 \mathrm{mmol})$ for $4 \mathrm{~h}$. The reaction mixture was cooled to room temperature, the separated solid filtered off, washed with a little cold ethanol and recrystallized from ethanol to give 7 . Yield $85 \%$; pale yellow powder; m.p. sharing at $230^{\circ} \mathrm{C}$; IR $(\mathrm{KBr}): v_{\max } 3205(\mathrm{NH})$, $1706(\mathrm{C}=\mathrm{O}$, amidic), 1625 ( $\alpha, \beta$-unsaturated $\mathrm{C}=\mathrm{O}), 1567$ $(\mathrm{C}=\mathrm{N}), 1548(\mathrm{C}=\mathrm{C}) \mathrm{cm}^{-1} ;{ }^{1} \mathrm{H}$ NMR (DMSO- $\left.d_{6}\right) \delta 1.74$, $1.79\left(2 \mathrm{~s}, 6 \mathrm{H}, 2 \mathrm{CH}_{3}\right), 6.08(\mathrm{~s}, 1 \mathrm{H}, \mathrm{CH}), 7.45-8.21(\mathrm{~m}, 3 \mathrm{H}$, $\mathrm{CH}$-pyridine ring), $8.47\left(\mathrm{~s}, 1 \mathrm{H}, \mathrm{C}_{2}-\mathrm{H}\right.$ of naphthyridine ring), $10.12(\mathrm{~s}, 1 \mathrm{H}, \mathrm{NH}) ;{ }^{13} \mathrm{C}$ NMR (DMSO- $\left.d_{6}\right) \delta 14.2,19.6$, $106.5,114,122.3,125.5,138,140.3,141.7,151.4,152.6$, 153.1, 176.8, 193.9; MS (EI, $70 \mathrm{eV}) \mathrm{m} / z$ (\%) $271\left(\mathrm{M}^{+}+3\right.$, 
0.8), $270\left(\mathrm{M}^{+}+2,0.5\right), 204$ (9.8), 174 (12.9), 173 (100), 145 (3.3), 120 (0.4), 105 (56.2), 95 (0.2), 90 (4.1), 78 (76.5); Anal. calcd. for $\mathrm{C}_{14} \mathrm{H}_{12} \mathrm{~N}_{4} \mathrm{O}_{2}(268.27)$ : C, 62.68; H, 4.51; N, 20.88. Found: C, 62.81; H, 4.60; N, 20.73.

\section{2. 6. Synthesis of $N^{\prime}-((2-H y d r o x y n a p h t h a l e n-$ 1-yl)methylene)-4-oxo-1,4-dihydro-1,8- naphthyridine-3-carbohydrazide (8)}

A mixture of $1(2.04 \mathrm{~g}, 10 \mathrm{mmol})$ and 2-hydroxy-1-naphthaldehyde $(1.72 \mathrm{~g}, 10 \mathrm{mmol})$ was refluxed in ethanol containing a catalytic amount of glacial acetic acid ( 5 drops) for $4 \mathrm{~h}$. The reaction mixture was cooled to room temperature, the separated product filtered off, dried, and recrystallized from ethanol to give the hydrazone derivative 8. Yield 92\%; pale yellow sheets; m.p. 176 ${ }^{\circ} \mathrm{C}$; IR (KBr): $v_{\max } 3450(\mathrm{OH}), 3330(\mathrm{NH}), 1702(\mathrm{C}=\mathrm{O}$, amidic), $1626(\alpha, \beta$-unsaturated $\mathrm{C}=\mathrm{O}), 1574(\mathrm{C}=\mathrm{N}) \mathrm{cm}^{-1}$; ${ }^{1} \mathrm{H}$ NMR (DMSO- $\left.d_{6}\right) \delta 1.89(\mathrm{~s}, 1 \mathrm{H}, \mathrm{CH}), 6.97-8.61(\mathrm{~m}$, 9H, Ar-H), 9.09 (s, 1H, $\mathrm{C}_{2}-\mathrm{H}$ of naphthyridine ring), 9.21 (s, 1H, NH), 9.68 (s, 1H, NH), 12.24 (s, 1H, NH), 12.95 (s, 1H, OH); Anal. calcd. for $\mathrm{C}_{20} \mathrm{H}_{14} \mathrm{~N}_{4} \mathrm{O}_{3}$ (358.35): C, 67.03; H, 3.94; N, 15.63. Found: C, 67.29; H, 3.78; N, 15.57 .

\section{2. 7. Synthesis of 3-(3H-Benzo[e] indazole-3- carbonyl)-1,8-naphthyridin-4(1H)-one (9)}

\section{Pathway 1}

Compound 8 ( $3.58 \mathrm{~g}, 10 \mathrm{mmol}$ ) was refluxed in ethanol containing a few drops of piperidine or triethylamine for $4 \mathrm{~h}$. The reaction mixture was cooled to room temperature, the separated product filtered off, dried, and recrystallized from ethanol to give compound $\mathbf{9}$.

\section{Pathway 2}

An equimolar amount of $1(2.04 \mathrm{~g}, 10 \mathrm{mmol})$ and 2-hydroxynaphthaldehyde ( $1.72 \mathrm{~g}, 10 \mathrm{mmol})$ in ethanol $(25 \mathrm{~mL})$ in the presence of a catalytic amount of piperidine or triethylamine (4 drops) or sodium ethoxide $(10 \mathrm{mmol})$ was refluxed for $3 \mathrm{~h}$. The reaction mixture was left to cool at room temperature overnight. The formed precipitate was filtered off, dried and recrystallized from ethanol to give compound 9. Yield 83\%; yellow powder; m.p. $291{ }^{\circ} \mathrm{C}$; IR (KBr): $v_{\max } 3340(\mathrm{NH}), 1710(\mathrm{C}=\mathrm{O}$, amidic), 1622 $(\alpha, \beta$-unsaturated $\mathrm{C}=\mathrm{O}), 1579(\mathrm{C}=\mathrm{N}), 1549(\mathrm{C}=\mathrm{C}) \mathrm{cm}^{-1} ;{ }^{1} \mathrm{H}$ NMR (DMSO- $\left.d_{6}\right) \delta 8.08\left(\mathrm{~s}, 1 \mathrm{H}, \mathrm{C}_{2}-\mathrm{H}\right.$ of naphthyridine ring), 8.20 (s, $1 \mathrm{H}, \mathrm{CH}$-pyrazole ring), 7.72-8.31 (m, 9H, Ar-H), 11.24 (s, $1 \mathrm{H}, \mathrm{NH}) ;{ }^{13} \mathrm{C}$ NMR(DMSO- $\left.d_{6}\right) \delta 113.5$, $118.0,121.6,122.8,123.6,124.4,124.7,124.9,125.7,127.2$, $127.3,127.8,134.6,141.9,151.2,152.5,161.7,164.3,177.5$; MS (EI, $70 \mathrm{eV}) \mathrm{m} / z(\%) 340\left(\mathrm{M}^{+}, 6.95\right), 208$ (3.42), 170 (26.02), 152 (13.20), 128 (19.71), 115 (72.86), 89 (13.88), 77 (8.22), 62 (13.54), 51 (17.97), 45 (100); Anal. calcd. for $\mathrm{C}_{20} \mathrm{H}_{12} \mathrm{~N}_{4} \mathrm{O}_{2}$ (340.33): C, 70.58; H, 3.55; N, 16.46. Found: C, $70.67 ; \mathrm{H}, 3.34 ; \mathrm{N}, 16.62$.

\section{2. 8. Synthesis of 3-(1H-Indazole-1-carbonyl)- 1,8-naphthyridin-4(1H)-one(10)}

An equimolar amounts of $1(2.04 \mathrm{~g}, 10 \mathrm{mmol})$ and salicyaldehyde $(1.22 \mathrm{~g}, 10 \mathrm{mmol})$ in ethanol $(25 \mathrm{~mL})$ in the presence of a catalytic amount of piperidine ( 4 drops) was refluxed for $3 \mathrm{~h}$. The reaction mixture was left to cool at room temperature overnight. The formed precipitate was filtered off, dried and recrystallized from ethanol to give compound 10. Yield 88\%; white powder; m.p. $286^{\circ} \mathrm{C}$; IR $(\mathrm{KBr}): v_{\max } 3073(\mathrm{NH}), 1667(\mathrm{C}=\mathrm{O}$, amidic), $1622(\alpha, \beta$-unsaturated $\mathrm{C}=\mathrm{O}), 1569(\mathrm{C}=\mathrm{N}), 1541(\mathrm{C}=\mathrm{C}) \mathrm{cm}^{-1}$; ${ }^{1} \mathrm{H}$ NMR $\left(\mathrm{DMSO}-d_{6}\right) \delta 8.70(\mathrm{~s}, 1 \mathrm{H}, \mathrm{CH}$-pyrazole ring), $9.08(\mathrm{~s}, 1 \mathrm{H}$, $\mathrm{C}_{2}-\mathrm{H}$ of naphthyridine ring), 6.90-9.24 (m, 5H, Ar-H), $11.28(\mathrm{~s}, 1 \mathrm{H}, \mathrm{NH}) ;{ }^{13} \mathrm{C} \mathrm{NMR}\left(\mathrm{DMSO}-d_{6}\right) \delta 114,115.4$, $121.5,121.9,122.3,123.9,125.5,127.6,128.3,138,143.2$, $151.4,152.6,153.1,176.8,193.9$; Anal. calcd. for $\mathrm{C}_{16} \mathrm{H}_{10} \mathrm{~N}_{4} \mathrm{O}_{2}(290.28): \mathrm{C}, 66.20 ; \mathrm{H}, 3.47 ; \mathrm{N}, 19.30$. Found: C, $66.15 ; \mathrm{H}, 3.56 ; \mathrm{N}, 19.35$.

\section{2. 9. Synthesis of 3-(3,4,6-Triamino- $2 \mathrm{H}$ - pyrazolo[3,4-b]pyridine-2-carbonyl)-1,8- naphthyridin-4(1H)-one (13)}

A mixture of $1(2.04 \mathrm{~g}, 10 \mathrm{mmol})$ and 2 -aminoprop-1-ene-1,1,3-tricarbonitrile $(1.32 \mathrm{~g}, 10 \mathrm{mmol})$ in ethanol $(25 \mathrm{~mL})$ containing a few drops of glacial acetic acid (5 drops) was refluxed for $4 \mathrm{~h}$. The reaction mixture was then cooled to room temperature and the obtained solid material filtered off, dried and recrystallized from ethanol to give pyrazolopyridine 13 . Yield $51 \%$; pale brown powder; m.p. $288^{\circ} \mathrm{C}$; IR (KBr): $v_{\max } 3411,3382\left(\mathrm{NH}_{2}\right), 3228$ (br, $\mathrm{NH}$ groups), 1671 ( $\mathrm{C}=\mathrm{O}$, amidic), $1628(\alpha, \beta$-unsaturated $\mathrm{C}=\mathrm{O}), 1608(\mathrm{C}=\mathrm{N}), 1569(\mathrm{C}=\mathrm{C}) \mathrm{cm}^{-1} ;{ }^{1} \mathrm{H}$ NMR (DM$\left.\mathrm{SO}-d_{6}\right) \delta 4.18\left(\mathrm{~s}, 4 \mathrm{H}, \mathrm{NH}_{2}\right), 5.90(\mathrm{~s}, 1 \mathrm{H}, \mathrm{CH}), 8.08(\mathrm{~s}, 1 \mathrm{H}$, $\mathrm{C}_{2}-\mathrm{H}$ of naphthyridine ring), 6.72-8.31 (m, 3H, CH-pyridine ring), 9.81 (s, 1H, NH), $11.60(\mathrm{~s}, 2 \mathrm{H}, 2 \mathrm{C}=\mathrm{NH}) ;{ }^{13} \mathrm{C}$ NMR (DMSO- $\left.d_{6}\right) \delta 89.1,95.1,118.0,121.6,123.6,134.6$, 147.0, 151.2, 152.5, 153.7, 159.8, 161.7, 162.4, 164.3, 177.5; MS (EI, $70 \mathrm{eV}) \mathrm{m} / z(\%) 336\left(\mathrm{M}^{+}, 38.85\right), 104$ (37.62), 90 (35.08), 84 (33.29), 78 (82.65), 64 (46.06), 54 (40.92), 53 (100), 50 (38.25), 48 (42.52); Anal. calcd. for $\mathrm{C}_{15} \mathrm{H}_{12} \mathrm{~N}_{8} \mathrm{O}_{2}$ (336.31): C, 53.57; H, 3.60; N, 33.32. Found: C, 53.34; H, $3.53 ; \mathrm{N}, 33.54$.

\section{2. 10. Synthesis of 3-Amino-5-(methylthio)-1- (4-oxo-1,4-dihydro-1,8-naphthyridine-3- carbonyl)-1H-pyrazole-4-carbonitrile (15)}

A mixture of 1 (2.04 g, $10 \mathrm{mmol}$ ) and 2-(bis(methylthio)methylene) malononitrile $(1.7 \mathrm{~g}, 10 \mathrm{mmol})$ in ethanol $(25 \mathrm{~mL})$ containing a few drops of glacial acetic acid was refluxed for $4 \mathrm{~h}$. The reaction mixture was then cooled to room temperature and the obtained solid material filtered off, dried and recrystallized from ethanol to give compound 15. Yield 90\%; yellow sheets; m.p. $254{ }^{\circ} \mathrm{C}$; IR (KBr): $v_{\max } 3413,3382\left(\mathrm{NH}_{2}\right), 3226$ (br, $\mathrm{NH}$ groups), 2200 
$(\mathrm{CN}), 1670(\mathrm{C}=\mathrm{O}$, amidic $), 1627(\alpha, \beta$-unsaturated $\mathrm{C}=\mathrm{O})$, $1608(\mathrm{C}=\mathrm{N}), 1569(\mathrm{C}=\mathrm{C}) \mathrm{cm}^{-1} ;{ }^{1} \mathrm{H}$ NMR (DMSO- $\left.d_{6}\right) \delta$ $1.96\left(\mathrm{~s}, 3 \mathrm{H}, \mathrm{SCH}_{3}\right), 4.52\left(\mathrm{~s}, 2 \mathrm{H}, \mathrm{NH}_{2}\right), 9.05\left(\mathrm{~s}, 1 \mathrm{H}, \mathrm{C}_{2}-\mathrm{H}\right.$ of naphthyridine ring), 7.60-8.24 ( $\mathrm{m}, 3 \mathrm{H}, \mathrm{CH}$-pyridine ring), $9.22(\mathrm{~s}, 1 \mathrm{H}, \mathrm{NH}), 10.66(\mathrm{~s}, 1 \mathrm{H}, \mathrm{NH}) ;{ }^{13} \mathrm{C}$ NMR (DMSO- $\left.d_{6}\right)$ $\delta 16.9,62.2,113.8,115.8,118.0,121.6,134.6,142.5,152.6$, 160.5, 161.7, 165.0, 177.5; MS (EI, $70 \mathrm{eV}) \mathrm{m} / z$ (\%) 327 $\left(\mathrm{M}^{+}+1,23.92\right), 294$ (31.62), 253 (15.05), 230 (24.34), 173 (31.75), 147 (18.32), 111 (39.36), 105 (28.04), 97 (18.55), 88 (15.66), 71 (29.92), 65 (24.72), 61 (34.46), 56 (100), 50 (26.79); Anal. calcd. for $\mathrm{C}_{14} \mathrm{H}_{10} \mathrm{~N}_{6} \mathrm{O}_{2} \mathrm{~S}(326.33)$ : C, 51.53; H, 3.09; N, 25.75. Found: C, 51.75; H, 3.13; N, 25.66.

\section{2. 11. Synthesis of 3-Imino-5-(4- methoxyphenylamino)-1-(4-oxo-1,4- dihydro-1,8-naphthyridine-3-carbon yl)- 2,3-dihydro-1H-pyrazole-4-carbonitrile} (16)

An equimolar amount of compound $15(3.26 \mathrm{~g}$, $10 \mathrm{mmol})$ and $p$-anisidine $(1.23 \mathrm{~g}, 10 \mathrm{mmol})$ in ethanol $(25$ $\mathrm{mL}$ ) in the presence of a few drops of piperidine was refluxed for $4 \mathrm{~h}$. The reaction mixture was left to cool at room temperature overnight. The formed precipitate was filtered off, dried and recrystallized from ethanol to give compound 16. Yield 65\%; dark yellow powder; m.p. 282 ${ }^{\circ} \mathrm{C}$; IR (KBr): $v_{\max } 3227$ (br, NH), $2200(\mathrm{CN}), 1669(\mathrm{C}=\mathrm{O}$, amidic), $1625(\alpha, \beta$-unsaturated $\mathrm{C}=\mathrm{O}), 1600(\mathrm{C}=\mathrm{N}), 1571$ $(\mathrm{C}=\mathrm{C}) \mathrm{cm}^{-1} ;{ }^{1} \mathrm{H}$ NMR (DMSO- $\left.d_{6}\right) \delta 3.52\left(\mathrm{~s}, 2 \mathrm{H}, \mathrm{OCH}_{3}\right)$, $9.05\left(\mathrm{~s}, 1 \mathrm{H}, \mathrm{C}_{2}-\mathrm{H}\right.$ of naphthyridine ring), 7.60-8.24 (m, $3 \mathrm{H}, \mathrm{CH}$-pyridine ring), $10.66(\mathrm{~s}, 1 \mathrm{H}, \mathrm{NH}), 10.82(\mathrm{~s}, 1 \mathrm{H}$, $\mathrm{C}=\mathrm{NH}) ;{ }^{13} \mathrm{C}$ NMR (DMSO- $\left.d_{6}\right) \delta 48,54.1,113.5(2 \mathrm{C})$, $113.6,113.8,114,115.4$ (2C), 122.3, 134.9, 138, 141.7, 149.5, 151.4, 152.6, 159.6, 160, 162, 176.8; MS (EI, $70 \mathrm{eV})$ $\mathrm{m} / z(\%) 401\left(\mathrm{M}^{+}, 9.49\right), 383$ (5.77), 318 (20.98), 308 (15.70), 245 (6.26), 227 (8.00), 211 (5.27), 207 (30.15), 201 (16.45), 186 (14.92), 173 (30.74), 120 (8.80), 108 (13.52), 77 (43.49), 68 (27.50), 52 (100); Anal. calcd. for $\mathrm{C}_{20} \mathrm{H}_{15} \mathrm{~N}_{7} \mathrm{O}_{3}$ (401.38): C, 59.85; H, 3.77; N, 24.43. Found: C, 59.95; H, 3.86; N, 24.61.

\section{2. 12. Synthesis of 5-Amino-3-(4-nitrophenyl)- 1-(4-oxo-1,4-dihydro-1,8-naphthyridine- 3-carbonyl)-2,3-dihydro-1H-pyrazole-4- carbonitrile (17)}

A mixture of $1(2.04 \mathrm{~g}, 10 \mathrm{mmol})$ in ethanol $(25 \mathrm{~mL})$ containing a few drops of glacial acetic acid (5 drops) and 2-(4-nitrobenzylidene)malononitrile (1.99 g, $10 \mathrm{mmol}$ ) was refluxed for $3 \mathrm{~h}$, then left to stand at room temperature overnight. The separated solid product was filtered off, dried and recrystallized from ethanol to give 17. Yield 85\%; dark yellow powder; m.p. $350{ }^{\circ} \mathrm{C}$; IR $(\mathrm{KBr}): v_{\max }$ 3468-3335 $\left(\mathrm{NH}_{2}\right), 1685(\mathrm{C}=\mathrm{O}$, amidic), 1629 ( $\alpha, \beta$-unsaturated $\mathrm{C}=\mathrm{O}), 1582(\mathrm{C}=\mathrm{N}), 1550(\mathrm{C}=\mathrm{C}), 1552,1336\left(\mathrm{NO}_{2}\right)$ $\mathrm{cm}^{-1} ;{ }^{1} \mathrm{H}$ NMR (DMSO- $\left.d_{6}\right) \delta 2.71\left(\mathrm{~s}, 2 \mathrm{H}, \mathrm{NH}_{2}\right), 5.29(\mathrm{~s}, 1 \mathrm{H}$,
$\mathrm{CH}), 9.11\left(\mathrm{~s}, 1 \mathrm{H}, \mathrm{C}_{2}-\mathrm{H}\right.$ of naphthyridine ring), 7.57-9.22 (m, 7H, Ar-H), 10.81 (s, 1H, NH), $12.28(\mathrm{~s}, 1 \mathrm{H}, \mathrm{NH}) ;{ }^{13} \mathrm{C}$ NMR (DMSO- $d_{6}$ ) $\delta 59.7,63.4,113.8,117.3,118.0,121.6$, 125.1, 128.3, 134.6, 142.5, 145.9, 149.4, 152.5, 158.1, 160.5, 161.7, 177.5; MS (EI, $70 \mathrm{eV}) \mathrm{m} / \mathrm{z}(\%) 403\left(\mathrm{M}^{+}, 100\right), 319$ (34.34), 266 (44.02), 218 (42.66), 212 (20.30), 204 (21.45), 146 (40.11), 141 (36.01), 105 (28.76), 97 (33.65), 60 (63.03); Anal. calcd. for $\mathrm{C}_{19} \mathrm{H}_{13} \mathrm{~N}_{7} \mathrm{O}_{4}(403.35)$ : C, $56.58 ; \mathrm{H}, 3.25 ; \mathrm{N}$, 24.31. Found: C, 56.71; H, 3.13; N, 24.26.

\section{2. 13. Synthesis of 5-Amino-3-(4-chlorophenyl)- 1-(4-oxo-1,4-dihydro-1,8-naphthyridine- 3-carbonyl)-2,3-dihydro-1H-pyrazole-4- carbonitrile (18)}

Equimolar quantities of the starting material 1 (2.04 g, $10 \mathrm{mmol})$ in ethanol $(25 \mathrm{~mL})$ containing a few drops of glacial acetic acid and 2-(4-chlorobenzylidene)malononitrile $(1.88 \mathrm{~g}, 10 \mathrm{mmol})$ were refluxed for $3 \mathrm{~h}$, then left to stand at room temperature overnight. The separated solid product was filtered off, dried and recrystallized from ethanol to give 18. Yield $93 \%$; yellow powder; m.p. $307^{\circ} \mathrm{C}$; IR $(\mathrm{KBr}): v_{\max } 3399-3341\left(\mathrm{NH}_{2}\right), 3260(\mathrm{NH}), 1679(\mathrm{C}=\mathrm{O}$, amidic), $1625(\alpha, \beta$-unsaturated $\mathrm{C}=\mathrm{O}), 765(\mathrm{C}-\mathrm{Cl}) \mathrm{cm}^{-1} ;{ }^{1} \mathrm{H}$ NMR (DMSO- $\left.d_{6}\right) \delta 2.83\left(\mathrm{~s}, 2 \mathrm{H}, \mathrm{NH}_{2}\right), 5.69(\mathrm{~s}, 1 \mathrm{H}, \mathrm{CH})$, $9.09\left(\mathrm{~s}, 1 \mathrm{H}, \mathrm{C}_{2}-\mathrm{H}\right.$ of naphthyridine ring), $6.72-8.31(\mathrm{~m}$, $7 \mathrm{H}, \mathrm{Ar}-\mathrm{H}), 10.83$ (s, 1H, NH), $11.40(\mathrm{~s}, 1 \mathrm{H}, \mathrm{NH}) ;{ }^{13} \mathrm{C} \mathrm{NMR}$ $\left(\right.$ DMSO- $\left.d_{6}\right) \delta 113.8,114,118,122.4,125.8$ (2C), 126.8 (2C) $131.2,131.5,135.5,138,141.6,150,151.4,153.1$, 161.5, 166.4, 176.2; MS (EI, $70 \mathrm{eV}) \mathrm{m} / z(\%) 392\left(\mathrm{M}^{+}-1\right.$, 0.01), 205 (0.11), 189 (77.30), 173 (100), 144 (21.49), 117 (10.94), 104 (45.37), 77 (47.32), 62 (16.20), 50 (31.49); Anal. calcd. for $\mathrm{C}_{19} \mathrm{H}_{13} \mathrm{ClN}_{6} \mathrm{O}_{2}(392.8)$ : $\mathrm{C}, 58.10 ; \mathrm{H}, 3.34 ; \mathrm{N}$, 21.40. Found: C, 58.06; H, 3.12; N, 21.38.

\section{2. 14. Synthesis of 3-(3,5-Diamino-1H-pyrazole- 1-carbonyl)-1,8-naphthyridin-4(1H)-one (19)}

Pathway 1

To a solution of $\mathbf{1}(2.04 \mathrm{~g}, 10 \mathrm{mmol})$ in ethanol $(25$ $\mathrm{mL}$ ) containing a few drops of glacial acetic acid, cyanoacetamide $(0.84 \mathrm{~g}, 10 \mathrm{mmol})$ was added and the reaction mixture was refluxed for $5 \mathrm{~h}$. The solution was cooled to room temperature, and the formed precipitate was filtered off, dried and recrystallized from ethanol to give pyrazole derivative 19.

\section{Pathway 2}

A mixture of $1(2.04 \mathrm{~g}, 10 \mathrm{mmol})$ in ethanol $(25 \mathrm{~mL})$ containing a few drops of glacial acetic acid and malononitrile $(0.66 \mathrm{~g}, 10 \mathrm{mmol})$ were refluxed for $3 \mathrm{~h}$, then left to stand at room temperature overnight. The separated solid product was filtered off, dried and recrystallized from ethanol to give 19. Yield $71 \%$; gray powder; m.p. $255^{\circ} \mathrm{C}$; IR $(\mathrm{KBr}): v_{\max } 3441\left(\mathrm{NH}_{2}\right), 3232$ (br, NH groups), 1668 (amid- 
ic $\mathrm{C}=\mathrm{O}), 1634(\alpha, \beta$-unsaturated $\mathrm{C}=\mathrm{O}), 1612(\mathrm{C}=\mathrm{N}), 1570$ $(\mathrm{C}=\mathrm{C}) \mathrm{cm}^{-1} ;{ }^{1} \mathrm{H}$ NMR (DMSO- $\left.d_{6}\right) \delta 4.01\left(\mathrm{~s}, 4 \mathrm{H}, 2 \mathrm{NH}_{2}\right)$, 6.37 (s, 1H, CH-pyrazole ring), 8.07 (s, 1H, $\mathrm{C}_{2}-\mathrm{H}$ of naphthyridine ring), 7.72-8.31 ( $\mathrm{m}, 3 \mathrm{H}, \mathrm{CH}$-pyridine ring), $10.20(\mathrm{~s}, 1 \mathrm{H}, \mathrm{NH}) ;{ }^{13} \mathrm{C}$ NMR (DMSO- $\left.d_{6}\right) \delta 78.6,118,121.6$, $123.6,134.6,148.2,151.2,152.5,161.7,164.3,177.5$; MS (EI, $70 \mathrm{eV}) \mathrm{m} / z(\%) 270\left(\mathrm{M}^{+}, 10\right), 173$ (28.63), 105 (76.12), 95 (0.40), 77 (100), 67 (20.41), 52 (38.72), and 50 (42.40); Anal. calcd. for $\mathrm{C}_{12} \mathrm{H}_{10} \mathrm{~N}_{6} \mathrm{O}_{2}(270.25): \mathrm{C}, 53.33 ; \mathrm{H}, 3.73 ; \mathrm{N}$, 31.10. Found: C, 53.46; H, 3.64; N, 31.29.

\section{3. Antitumor Activity (or Cytotoxicity) Using In Vitro Ehrlich Ascites Assay}

The isolated compounds were screened for their antitumor activity. The viability of the cells used in control experiments exceeded 95\%. Different concentrations of the tested compounds were prepared (100, 50 and $25 \mu \mathrm{L}$ from $1 \mathrm{mg} / \mathrm{mL}$ in DMSO (<00.05\%, v/v) and complete to $1 \mathrm{~mL}$ using RPMI-1640 medium). 5-Fluorouracil (25 $\mu \mathrm{g} /$ $\mathrm{mL}$ ) was prepared in $100 \mu \mathrm{L}$ DMSO and complete to $1 \mathrm{~mL}$ using RPMI-1640 medium. Ehrlich ascites Carcinoma (EAC) were derived from ascetic fluid from diseased mouse (purchased from National Cancer Institute, by National Medical Research Ethics Committee). Ascites fluid from the peritoneal cavity of the diseased mouse (containing Ehrlich cells) was aseptically aspirated. The cells were grown partly floating and partly attached in a suspension culture in RPMI 1640 medium, supplemented with $10 \%$ fetal bovine serum. They were maintained at $37{ }^{\circ} \mathrm{C}$ in a humidified atmosphere with $5 \% \mathrm{CO}_{2}$ for $2 \mathrm{~h}$. The viability of the cells was determined by the microscopical examination using a hemocytometer and using trypan blue stain (that stains only the dead cells). ${ }^{14}$

\section{4. Antioxidant Activity Screening Assay 2,2'-Azino-bis-3-ethylbenzthiazoline-6- sulfonic Acid Method}

For each of the investigated compounds, $2 \mathrm{~mL}$ of ABTS solution $(60 \mu \mathrm{M})$ was added to $3 \mathrm{~mL} \mathrm{MnO}_{2}$ solution (25 mhg/mL), all prepared in $5 \mathrm{~mL}$ aqueous phosphate buffer solution ( $\mathrm{pH} \mathrm{7;0.1} \mathrm{M).} \mathrm{The} \mathrm{mixture} \mathrm{was} \mathrm{shaken,}$ centrifuged, filtered, and the absorbance of the resulting green-blue solution (ABTS radical solution) at $\lambda 734 \mathrm{~nm}$ was adjusted to approximately 0.5 . Then, $50 \mu \mathrm{L}$ of $2 \mathrm{Mm}$ solution of the tested compound in spectroscopic grade
$\mathrm{MeOH} /$ phosphate buffer (1:1) was added. The absorbance was measured and the reduction in color intensity was expressed as inhibition percentage. L-Ascorbic acid was used as the standard antioxidant (positive control). Blank sample was run without ABTS and using $\mathrm{MeOH} /$ phosphate buffer (1:1) instead of the tested compounds. Negative control was run with ABTS and $\mathrm{MeOH} /$ phosphate buffer (1: 1) only. ${ }^{15,16}$ The inhibition ratio (\%) was calculated using the following formula:

$$
\text { (\%)Inhibition }=\frac{A(\text { control })-A(\text { test })}{A(\text { control })} \times 100
$$

\section{Results and Discussion}

\section{1. Chemistry}

In view of these observations and in continuation of our previous work in quinazoline chemistry, ${ }^{17,18}$ we synthesized some new heterocyclic compounds containing quinazoline moiety to evaluate their biological activities. The synthetic procedures adopted to obtain the target compounds are depicted in Schemes 1-10. The starting material, 1,4-dihydro-4-oxo-1,8-naphthyridine-3-carbohydrazide $(\mathbf{1})^{19}$ when heated with benzoxazine derivative $2^{12}$ in refluxing ethanol containing a catalytic amount of glacial acetic acid afforded 1,4-dihydro- $N$-(2-methyl-4oxoquinazolin-3(4H)-yl)-4-oxo-1,8-naphthyridine-3-carboxamide (3) (Scheme 1).

The IR spectrum showed absorption bands at 3230$3238,1668,1671,1614$, and $1569 \mathrm{~cm}^{-1}$ corresponding to stretching vibrations of two $\mathrm{NH}$, amidic carbonyl groups, $\alpha, \beta$-unsaturated ketone, and $\mathrm{C}=\mathrm{N}$ groups. ${ }^{1} \mathrm{H}$ NMR spectrum revealed singlet signal at $\delta 1.93 \mathrm{ppm}$ due to methyl protons, in addition to the classical pattern of 1,8-naphthyridine protons. The mass spectrum provided more evidence for the correct structure, which showed the molecular ion peak at $m / z 347\left(\mathrm{M}^{+}\right)$.

Compound 1 when reacted with ethyl acetoacetate in refluxing ethanol containing a catalytic amount of glacial acetic acid afforded the acyclic intermediate ethyl 3-(2-(4-oxo-1,4-dihydro-1,8-naphthyridine-3-carbonyl) hydrazono)butanoate (4). Heating compound 4 in boiling ethanol containing sodium ethoxide leads to cyclization with the formation of the pyrazolone derivative 3-(3-methyl-5-oxo-4,5-dihydro-1H-pyrazole-1-carbonyl)-1,8-naphthyridin-4(1H)-one (5) (Scheme 2).<smiles></smiles>

Scheme 1 


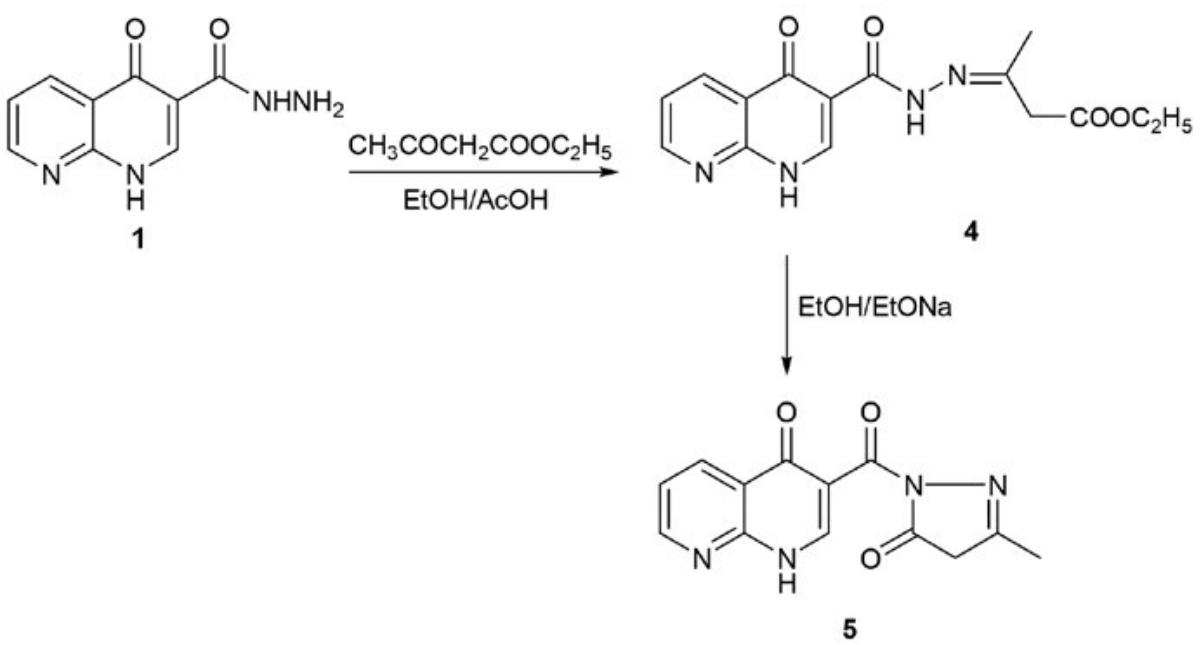

Scheme 2

Similarly, the hydrazide 1 when subjected to react with acetyl acetone in refluxing ethanol containing a catalytic amount of glacial acetic acid afforded the acyclic hydrazone derivative 4-oxo- $N$-(4-oxopentan-2-ylidene)1,4-dihydro-1,8-naphthyridine-3-carbohydrazide which when refluxed with ethanol containing sodium ethoxide afforded the pyrazole derivative 3-(3,5-dimethyl-1H-pyrazole-1-carbonyl)-1,8-naphthyridin-4(1H)-one (7) (Scheme 3).

Structures 4-7 were proved by elemental and spectral analyses. The IR spectra of compounds $\mathbf{4}$ and $\mathbf{6}$ in general showed absorption frequencies at 1567-1569, 1724, and $1689 \mathrm{~cm}^{-1}$ corresponding to $\mathrm{C}=\mathrm{N}$ and two $\mathrm{C}=\mathrm{O}$ due to ketonic (ester), and amidic carbonyl functional groups, while the ${ }^{1} \mathrm{H}$ NMR spectrum of compound 4 showed a characteristic signal at $\delta 0.91 \mathrm{ppm}$ as a singlet signal for $\mathrm{CH}_{3}$ protons, $\delta 1.38 \mathrm{ppm}$ as a triplet signal for $\mathrm{CH}_{3}$ protons, $\delta 2.35 \mathrm{ppm}$ as a singlet signal for $\mathrm{CH}_{2}$ protons and at $\delta 4.25 \mathrm{ppm}$ as a quartet signal for $\mathrm{CH}_{2}$ protons besides the aromatic protons of pyridine ring at $\delta 7.60-8.24 \mathrm{ppm}$, and a singlet signal at $8.61 \mathrm{ppm}$ due to $\mathrm{C}_{2}-\mathrm{H}$ of naphthyridine ring. On the other hand, the ${ }^{1} \mathrm{H}$ NMR spectrum of compound 6 showed three singlet signals at $\delta 1.20,2.11,2.54$ ppm corresponding to two methyl protons and $\mathrm{CH}_{2}$ protons, respectively. In addition, the mass spectrometry measurement gave $\mathrm{m} / z 316\left(\mathrm{M}^{+}\right)$and $286\left(\mathrm{M}^{+}\right)$corresponding to the molecular ion peaks of compounds 4 and 6, respectively. For the pyrazole derivative 5 the IR spectrum showed a new absorption band at $1669 \mathrm{~cm}^{-1}$ corresponding to a new amidic carbonyl and absorption frequency at $1606 \mathrm{~cm}^{-1}$ corresponding to $\mathrm{C}=\mathrm{N}$ stretching frequency while the IR spectrum of compound 7 showed stretching frequency at $1567 \mathrm{~cm}^{-1}$ due to $\mathrm{C}=\mathrm{N}$ functional group. ${ }^{1} \mathrm{H}$ NMR of compound 5 showed two new singlet signals at $\delta 1.22$ and $2.07 \mathrm{ppm}$ corresponding to methyl and methylene protons of pyrazolone moiety. On the other hand, the ${ }^{1} \mathrm{H}$ NMR spectrum of compound 7 revealed three singlet signals at $\delta 1.74,1.79$, and $6.08 \mathrm{ppm}$ attribut-<smiles>CCOC(=O)CCC(=O)OCC(C)(C)C</smiles><smiles>CC(=O)C/C(C)=N\NC(=O)c1c[nH]c2ncccc2c1=O</smilesEtOH/EtONa $\checkmark$<smiles>Cc1cc(C)n(C(=O)c2c[nH]c3ncccc3c2=O)n1</smiles>

7 
able to two methyl groups and methine protons of pyrazole moiety. The mass spectra of compounds 5 and 7 showed their molecular ion peak at $m / z 270\left(\mathrm{M}^{+}\right)$and 270 $\left(\mathrm{M}^{+}+2\right)$, respectively.

In a similar manner, it was found that 2-hydroxy-1-naphthaldehyde when reacted with hydrazide 1 in ethanol containing a catalytic amount of glacial acetic acid afforded the hydrazone derivative 8 . Hydrazone $8 \mathrm{cy}$ clized to the corresponding pyrazole derivative 3 - $3 H$-benzo[e] indazole-3-carbonyl)-1,8-naphthyridin-4-( $1 H)$-one (9) when heated in ethanol containing a catalytic amount of piperidine or triethylamine (Scheme 4).

Structures $\mathbf{8}$ and $\mathbf{9}$ were proved based on the correct analytical and spectral data. The IR of compound $\mathbf{8}$ showed bands at 3450 and $1574 \mathrm{~cm}^{-1}$ corresponding to the hydrox$\mathrm{yl}$ group and stretching vibration of $\mathrm{C}=\mathrm{N}$ function. Compound 9 was confirmed by analytical and spectral data, beside it was confirmed chemically by an alternative synthesis. Thus, when hydrazide 1 reacted with 2-hydroxy-1-naphthaldehyde in refluxing ethanol containing a catalytic amount of pipridine or triethylamine or sodium ethoxide afforded directly the corresponding pyrazole derivative 9 . The IR spectrum of compound 9 showed bands at $1579 \mathrm{~cm}^{-1}$ corresponding to $\mathrm{C}=\mathrm{N}$ function, and the disappearance of the band around $3450 \mathrm{~cm}^{-1}$ corresponding to hydroxyl group which indicates that the hydroxyl group was involved in the cyclization process. The ${ }^{1} \mathrm{H}$ NMR spec- trum showed a characteristic singlet signal at $\delta 8.20 \mathrm{ppm}$ due to the pyrazole $\mathrm{CH}$ proton plus the classical ${ }^{1} \mathrm{H}$ NMR pattern of the rest of 1,8-naphthyridine protons. The mass spectroscopic measurement gives an additional confirmation for compound $\mathbf{9}$ which showed the molecular ion peak at $m / z 340\left(\mathrm{M}^{+}\right)$.

In addition, salicylaldehyde when heated directly with the hydrazide 1 in refluxing ethanol containing a catalytic amount of piperidine or triethylamine afforded the corresponding pyrazole derivative 3 - $(1 \mathrm{H}$-indazole-1-carbonyl)-1,8-naphthyridin-4(1H)-one (10) (Scheme 4).

The IR spectrum of pyrazole derivative $\mathbf{1 0}$ showed a characteristic absorption band at $1569 \mathrm{~cm}^{-1}$ corresponding to $\mathrm{C}=\mathrm{N}$ function and the disappearance of any band around the region $3400 \mathrm{~cm}^{-1}$ corresponding to hydroxyl group. ${ }^{1} \mathrm{H}$ NMR spectrum showed singlet signal at $\boldsymbol{\delta} 8.70$ ppm attributable to the pyrazole proton. The mass spectroscopic measurement gives an additional confirmation for compound $\mathbf{1 0}$ which showed the molecular ion peak at $m / z 290\left(\mathrm{M}^{+}\right)$.

An interesting reaction was observed when hydrazide 1 was heated with malononitrile dimmer (11) in refluxing ethanol containing a catalytic amount of glacial acetic acid affording the pyrazolopyridine 3-(3,4,6-triamino- $2 H$-pyrazolo[3,4- $b$ ]pyridine-2-carbonyl)- 1,8 naphthyridin-4(1H)-one (13) via the non isolable intermediate 12. The reaction may be preceded first by addi-

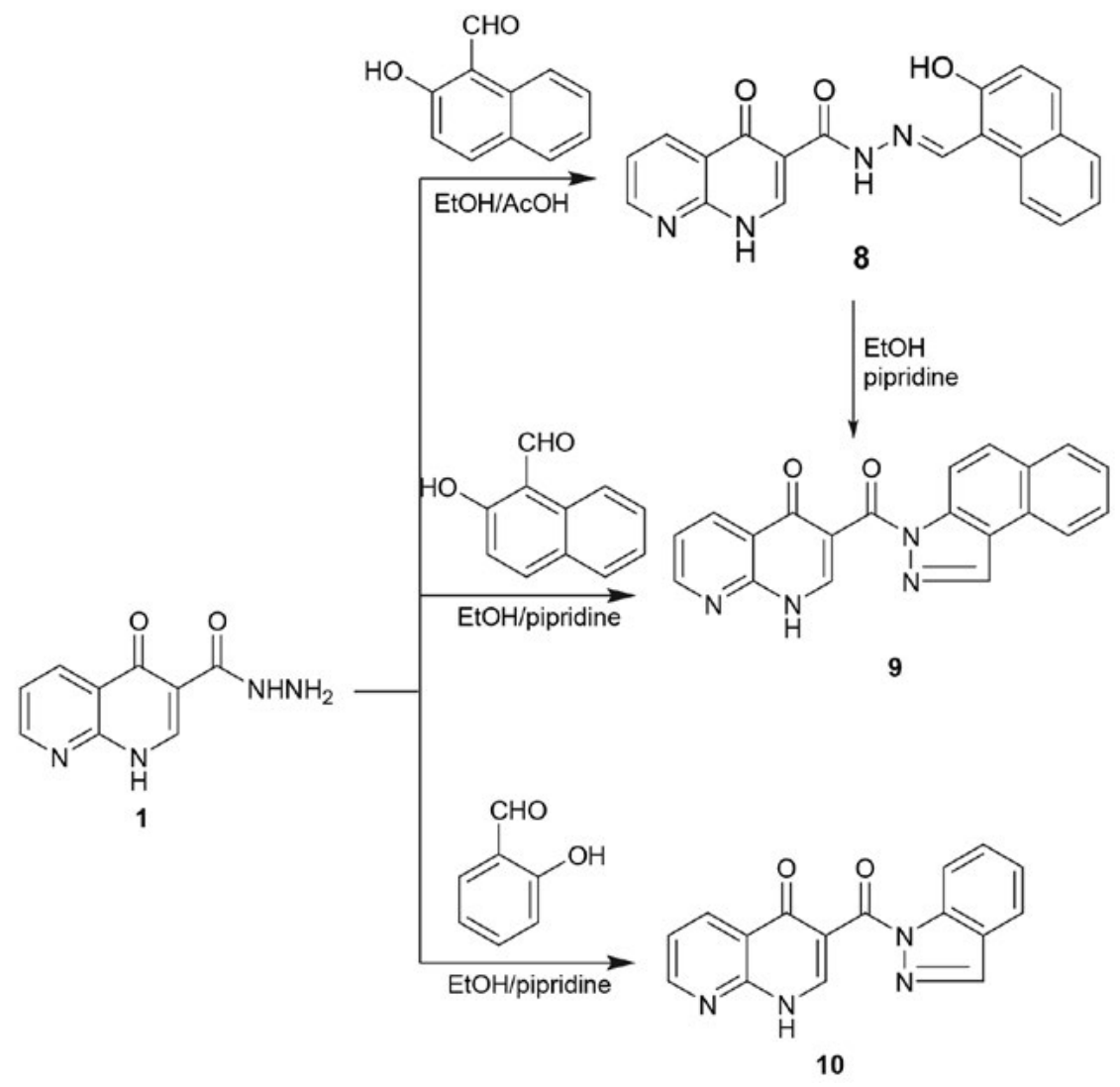

Scheme 4 


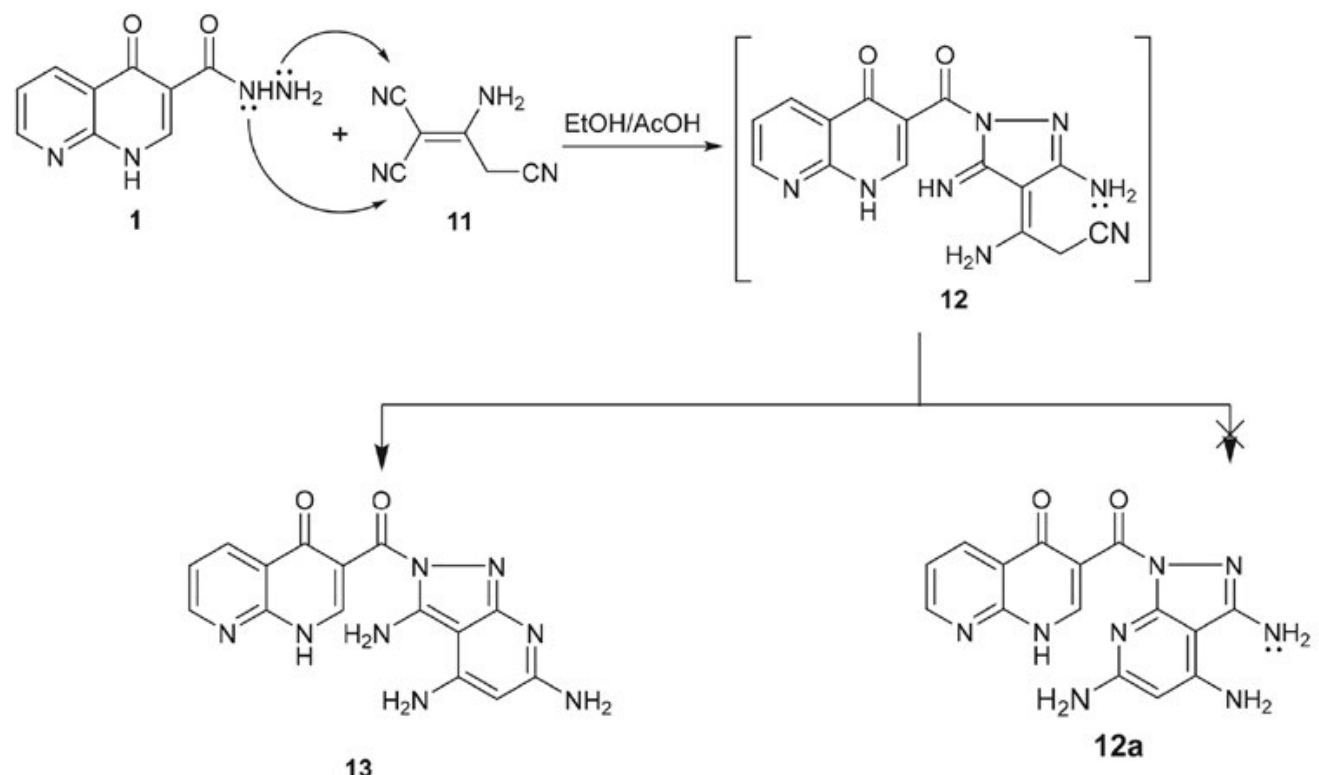

Scheme 5

tion of $\mathrm{NHNH}_{2}$ moiety to the two cyano groups with the formation of a pyrazole ring. The reaction followed by the attack of the lone pair of electrons of $\mathrm{NH}_{2}$ of pyrazole ring to the cyano group as shown in the following mechanism affording the pyrazolopyridine $\mathbf{1 3}$ and not the other possibility 12a because the exocyclic double bond will be more stable in the $Z$-form due to less steric hindrance. This fact confirms that nucleophilic addition occurred from $\mathrm{NH}_{2}$ group and not imino group. (Scheme 5).

The IR spectrum of compound 13 showed absorption bands at $3411,3382 \mathrm{~cm}^{-1}$ due to $\mathrm{NH}_{2}$ functions, besides a broad band at $3228 \mathrm{~cm}^{-1}$ for NH groups, 1671 and $1608 \mathrm{~cm}^{-1}$ corresponding to amidic $\mathrm{C}=\mathrm{O}, \mathrm{C}=\mathrm{N}$ and the disappearance of any band due to cyano functions at 2220 $\mathrm{cm}^{-1}$ which indicate that the cyano group was involved in the cyclization reaction. The ${ }^{1} \mathrm{H}$ NMR showed four singlet exchangeable signals at $\delta 4.18,9.81$, and $11.60 \mathrm{ppm}$ attributable to one amino group and three NH protons, respectively. The mass spectrum showed the molecular ion peak at $m / z 336\left(\mathrm{M}^{+}\right)$.

The hydrazide 1 when heated with dimethylthiomethylene malonate (14) in the presence of ethanol containing a few drops of glacial acetic acid afforded the pyrazole derivative 15 (Scheme 6). The reaction proceeds according to the proposed following mechanism.

The IR spectrum of compound 15 showed absorption bands at $3413,3382 \mathrm{~cm}^{-1}$ corresponding to $\mathrm{NH}_{2}$ group, $3226 \mathrm{~cm}^{-1}$ due to $\mathrm{NH}$ function, 1670 and $1608 \mathrm{~cm}^{-1}$ corresponding to amidic $\mathrm{C}=\mathrm{O}$ and $\mathrm{C}=\mathrm{N}$ and a characteristic absorption band at $2220 \mathrm{~cm}^{-1}$ corresponding to $\mathrm{CN}$ group. The ${ }^{1} \mathrm{H}$ NMR revealed a characteristic singlet signal of thiomethyl group at $\boldsymbol{\delta} 1.96 \mathrm{ppm}$ and three exchangeable

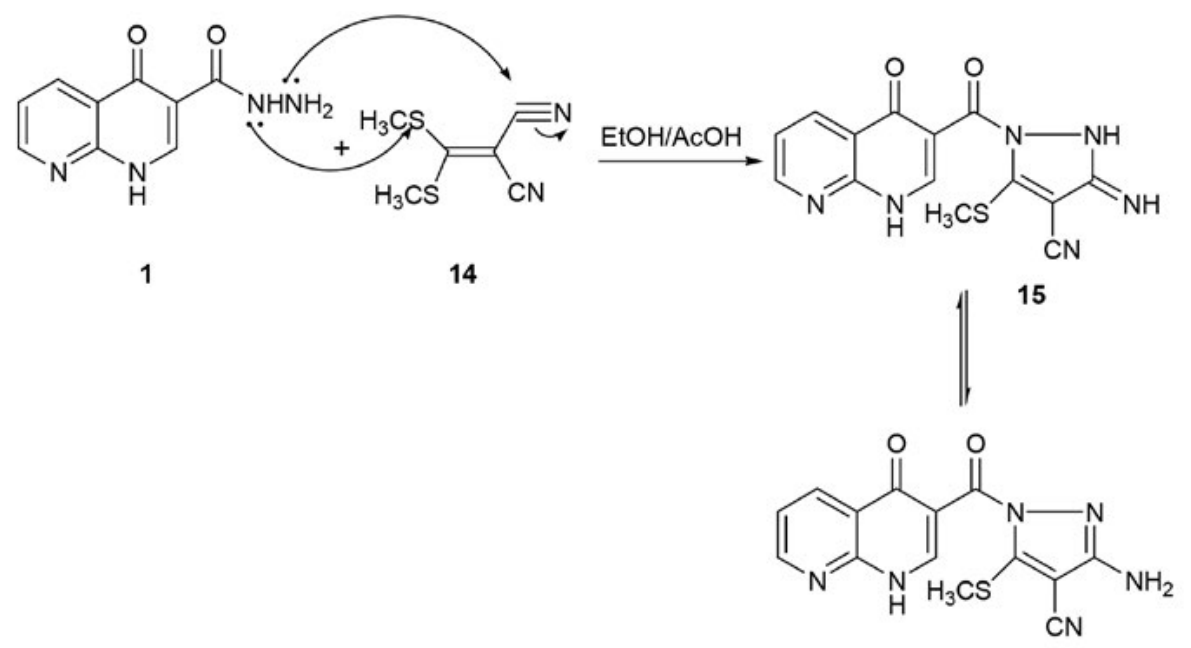


<smiles>CSc1c(C#N)c(N)nn1C(=O)c1c[nH]c2ncccc2c1=O</smiles>

15

Scheme 7

singlet signals at $\boldsymbol{\delta} 4.52,9.22$, and $10.66 \mathrm{ppm}$ attributable to $\mathrm{NH}_{2}$ and $\mathrm{NH}$ protons. The mass spectrum showed the molecular ion peak at $m / z 327\left(\mathrm{M}^{+}+1\right)$.

In addition, when compound $\mathbf{1 5}$ was subjected to react with $p$-anisidine in ethanol containing a catalytic amount of triethlylamine afforded 3-imino-5-(4-methoxyphenylamino)-1-(4-oxo-1,4-dihydro-1,8-naphthyridine-3-carbonyl)-2,3-dihydro-1H-pyrazole-4-carbonitrile (16) (Scheme 7).

Also, it has been found that when hydrazide 1 reacted with $p$-nitrobenzylidene malononitrile and $p$-chlorobenzylidene malononitrile in ethanol containing a few drops of glacial acetic acid afforded the pyrazole derivatives 5-amino-3-(4-nitrophenyl)-1-(4-oxo-1,4-dihydro1,8-naphthyridine-3-carbonyl)-2,3-dihydro- $1 H$-pyrazole-4-carbonitrile (17) or 5-amino-3-(4-chlorophenyl)1-(4-oxo-1,4-dihydro-1,8-naphthyridine-3-carbonyl)-2,3-dihydro-1H-pyrazole-4-carbonitrile (18), respectively (Scheme 8).

Structures 17 and 18 were proved based on the analytical and spectral data. The IR spectrum of both compounds showed, in general, characteristic absorption bands at 1582 and $1550 \mathrm{~cm}^{-1}$ corresponding to stretching frequencies of $\mathrm{C}=\mathrm{N}$ and $\mathrm{C}=\mathrm{C}$ functions, respectively. The ${ }^{1} \mathrm{H}$ NMR of both compounds showed a characteristic sin- glet signal at $\boldsymbol{\delta} 5.29$ and 5.69 ppm attributable to methyne protons. The mass spectra of compounds 17 and 18 showed the molecular ion peak at $m / z 403\left(\mathrm{M}^{+}\right)$and 392 $\left(\mathrm{M}^{+}-1\right)$, respectively.

Moreover, when hydrazide 1 reacted with cyanoacetamide in refluxing ethanol in the presence of a catalytic amount of glacial acetic acid afforded the diaminopyrazole derivative 3-(3,5-diamino-1H-pyrazole-1-carbonyl)-1,8naphthyridin-4(1H)-one (19). The same compound was obtained when the hydrazide $\mathbf{1}$ was subjected to react with malononitrile under the same reaction conditions (Scheme 9).

Structure 19 was established based on both analytical and spectral data. The IR spectrum showed the classical pattern for carbonyl groups which appear at 1668 and $1634 \mathrm{~cm}^{-1}$, and showed the stretching vibration of $\mathrm{C}=\mathrm{N}$ and $\mathrm{C}=\mathrm{C}$ functions at 1612 and $1570 \mathrm{~cm}^{-1}$, respectively. On the other hand, the amino groups appeared as a tautomeric equilibrium with amino-imino groups and appeared at 3441 and $3232 \mathrm{~cm}^{-1}$, respectively. ${ }^{1} \mathrm{H}$ NMR of compound 19 revealed two exchangeable signals at $\boldsymbol{\delta} 4.01$ and 10.20 ppm due to two $\mathrm{NH}_{2}$ and $\mathrm{NH}$ protons, in addition to two singlet signals at $\boldsymbol{\delta} 6.37$ and $8.07 \mathrm{ppm}$ for $\mathrm{CH}$-pyrazole and $\mathrm{C}_{2}-\mathrm{H}$ of naphthyridine ring, besides aromatic protons of pyridine ring at $\boldsymbol{\delta} 7.72-8.31 \mathrm{ppm}$. The mass spectrum gave

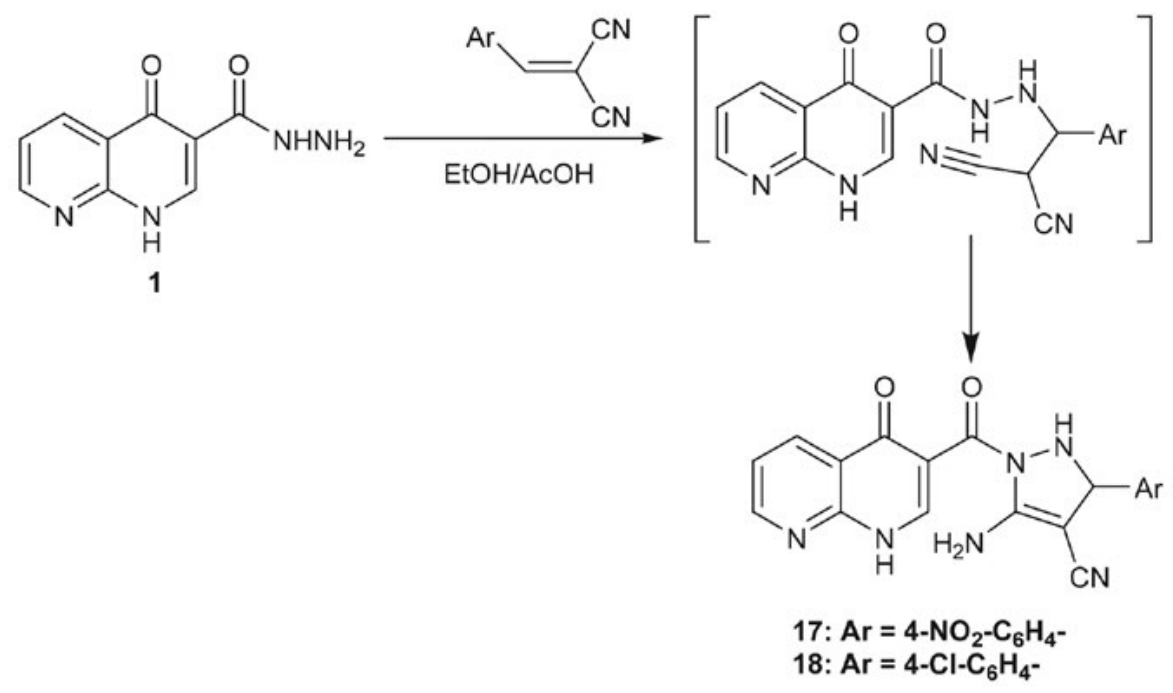


<smiles>NNC(=O)c1c[nH]c2ncccc2c1=O</smiles><smiles>CCOC(=O)O</smiles><smiles>Nc1cc(N)n(C(=O)c2c[nH]c3ncccc3c2=O)n1</smiles>

19<smiles>N#CCC#N</smiles>

\section{$\mathrm{EtOH} / \mathrm{AcOH}$}<smiles>N=C1CC(=N)N(C(=O)c2c[nH]c3ncccc3c2=O)N1</smiles>

Scheme 9

additional evidence for structure 19 which showed its molecular ion peak at $\mathrm{m} / z 270\left(\mathrm{M}^{+}\right)$.

\section{2. Pharmacology}

\section{2. 1. Cytotoxicity Against Ehrlich Ascites Carcinoma}

\section{Effect of Drugs on the Viability of Ehrlich Ascites Cells In Vitro}

The synthesis, antitumor evaluation and QSAR studies of novel pyrazol derivatives employed against Ehrlich Ascites Carcinoma (EAC, in vitro) cells are described. These novel analogues were molecularly designed with the goal of having significant potent cytotoxic effect against EAC cells.

Pyrazoles and related analogues were tested for cytotoxicity against EAC in vitro. EAC cells were used because they have a very well known established model of activity. ${ }^{20}$ Results for the ED25 value of the active compounds are summarized in Table 1 . The data showed clearly that compound 15 showed moderate activity ( 45\%) compar- ing with the drug reference (5-FU, 98\% activity). The rest of compounds showed weak activity. Thus, it would appear that introducing thiomethyl tautomeric moiety enhanced the cytotoxic properties.

Comparing the obtained cytotoxic activity of tested compounds in this study, the following structure-activity relationships (SAR) were postulated:

1) Compound $\mathbf{1 5}$ showed a mild cytotoxic activity $(\sim 45 \%)$, this may be due to the presence of thiomethyl and cyano groups which have toxic activity in nature.

2) All pyrazole derivatives showed weak activity at ED25. Thus the position and nature of substituents in the structure of pyrazole derivatives seems to modulate cytotoxic activity.

\section{2. 2. ABTS Antioxidant Activity Screening}

The antioxidant activity assay employed here is one of the several assays that depends on measuring the consumption of stable free radicals, i.e. evaluates the free rad-

Table 1. In vitro cytotoxicity of pyrazol against Ehrlich Ascites Carcinoma

\begin{tabular}{|c|c|c|c|c|c|}
\hline \multirow[t]{2}{*}{$\begin{array}{l}\text { Compound } \\
\text { No. }\end{array}$} & \multicolumn{2}{|c|}{$\begin{array}{c}\text { EAC Assay } \\
\text { Dead cells }(\%) \\
\text { ED25 } \mu \mathrm{L}(1 \mathrm{mg} / \mathrm{mL}) \\
\text { Control } 0\end{array}$} & \multirow[t]{2}{*}{$\begin{array}{c}\text { Compound } \\
\text { No. }\end{array}$} & \multicolumn{2}{|c|}{$\begin{array}{c}\text { EAC Assay } \\
\text { Dead cells }(\%) \\
\text { ED25 } \mu \mathrm{L}(1 \mathrm{mg} / \mathrm{mL}) \\
\text { Control } 0\end{array}$} \\
\hline & 5-FU & 98 & & 5-FU & 98 \\
\hline 3 & 0 & & 15 & 45 & \\
\hline 7 & 28 & & 16 & 19 & \\
\hline 8 & 20 & & 17 & 21 & \\
\hline 9 & 14 & & 18 & 17 & \\
\hline 10 & 11 & & 19 & 14 & \\
\hline 13 & & & & 23 & \\
\hline
\end{tabular}

Where ED25 is the effective dose at $25 \mu \mathrm{L}$ of the compounds used.

The dead \% refers to the \% of the dead tumor cells and 5-Flu is 5 -fluorouracil as a well known cytotoxic agent. 
ical scavenging activity of the investigated component. The methodology assumes that the consumption of the stable free radical ( $\left.\mathrm{X}^{\prime}\right)$ will be determined by the reaction as follows:

$$
\mathrm{XH}+\mathrm{Y}^{\prime} \longrightarrow \mathrm{X}^{\prime}+\mathrm{YH}
$$

The rate and/or the extent of the process measured in terms of the decrease in $\mathrm{X}^{\prime}$ concentration, would be related to the ability of the added compounds to trap free radicals. The decrease in color intensity of the free radical solution due to scavenging of the free radical by the antioxidant material is measured colorimetrically at a specific wavelength. The assay employs the radical cation derived from 2,2'-azino-bis(3-ethyl benzthiazoline-6-sulfonic acid) (ABTS) as a stable free radical to assess antioxidant potential of the isolated compounds and extracts. The advantage of ABTS-derived free radical method over other methods is that the produced color remains stable for more than one hour and the reaction is stoichiometric. The inhibition ratio (\%) was calculated using the following formula:

$$
\text { (\%) Inhibition }=\frac{A(\text { control })-A(\text { test })}{A(\text { control })} \times 100
$$

The antioxidant activity of some newly synthesized compounds was evaluated by ABTS method. ${ }^{21}$ The data in Table 2 showed clearly that compound $\mathbf{1 5}$ demonstrated moderate antioxidant activities. Thus, it would appear that introducing sulfur atoms and the presence of thiomethyl tautomeric equilibrium enhances the antioxidant properties of 1,8-naphthyridine derivatives. By comparing the results obtained of antioxidant of the compound reported in this study to their structures, the following SAR was postulated: compound $\mathbf{1 5}$ was nearly inpotent to vitamin $\mathrm{C}$ which may be attributed to the presence of amino and imino groups which trap the free radical X.

\section{Conclusion}

This work aimed to synthesize a new series of pyrazole derivatives containing 1,8-naphthyridine ring via carboxamide linkage. All the structures of the synthesized compounds were confirmed by different spectroscopic data and screened for their in vitro cytotoxicity against EAC and antioxidant activity. Results obtained show that compound $\mathbf{1 5}$ displayed the best cytotoxicity and antioxidant activity.

\section{References}

1. H. Egawa, T. Miyamota, A. Minamida, Y. Nishimura, H. Okada, H. Uno, T. Motosumota, J. Med. Chem. 1984, 27, 15431548. DOI:10.1021/jm00378a004

2. K. Kohima, M. Motoyoshi, Japan Kotai Tokyo JP 1988, 01,100,603; Chem. Abstr. 1988, 109, 189591.

3. C. S. Cooper, P. L. Klock, D. T. W. Chu, D. J. Hardy, R. N. Swanson, J. J. Plattner, J. Med. Chem. 1992, 35, 1392-1398.

DOI:10.1021/jm00086a007

4. J. Nezval, K. Halocka, Experientia 1967, 23, 1043-1044. DOI:0.1007/BF02136439

5. K. Tomita, Y. Tsuzuki, K. Shibamori, M. Tshima, F. Kajikawa, Y. Sato, S. Kashimoto, K. Chiba, K. Hino, J. Med. Chem. 2002, 45, 5564-5575. DOI:10.1021/jm010057b

6. Y. Tsuzuki, K. Tomita, K. Shibamori, Y. Sato, S. Kashimoto, K. Chiba, J. Med. Chem. 2004, 47, 2097-2109.

DOI:10.1021/jm0304966

7. S. K. Srivastava, M. Jaggi, A. T. Singh, A. Madaan, N. Rani, M. Vishnoi, S. K. Agarwal, R. Mukherjee, A. C. Burman, Bioorg. Med. Chem. Lett. 2007, 17, 6660-6664.

DOI:10.1016/j.bmcl.2007.08.006

8. M. Lovu, C. Zalaru, F. Dumitrascu, C. Draghici, M. Moraru, E. Criste, Farmaco., 2003, 58, 301-307. http://www.sciencedirect.com/science/article/pii/ S0014827X02000149

Table 2. Antioxidant assay for some prepared new compounds.

\begin{tabular}{ccc}
\hline $\begin{array}{c}\text { Compound } \\
\text { No. }\end{array}$ & $\begin{array}{c}(\%) \text { Inhibition }=\frac{A(\text { control })-A(\text { test })}{A(\text { control })} \\
\text { ABTS }\end{array}$ \\
& Absorbance of samples & Inhibition) \\
\hline Control of ABTS & 0.47 & $0 \%$ \\
Ascorbic acid & 0.06 & $87.0 \%$ \\
$\mathbf{3}$ & 0.42 & $10.6 \%$ \\
$\mathbf{7}$ & 0.31 & $34.0 \%$ \\
$\mathbf{8}$ & 0.35 & $25.5 \%$ \\
$\mathbf{9}$ & 0.36 & $23.4 \%$ \\
$\mathbf{1 0}$ & 0.37 & $21.3 \%$ \\
$\mathbf{1 3}$ & 0.31 & $34.0 \%$ \\
$\mathbf{1 5}$ & $\mathbf{0 . 1 9}$ & $\mathbf{5 9 . 6 \%}$ \\
$\mathbf{1 6}$ & 0.35 & $25.5 \%$ \\
$\mathbf{1 7}$ & 0.34 & $27.6 \%$ \\
$\mathbf{1 8}$ & 0.35 & $25.5 \%$ \\
$\mathbf{1 9}$ & 0.34 & $27.6 \%$ \\
\hline
\end{tabular}


9. R. N. Mahajan, F. H. Havaldar, P. S. Fernandes, Indian J. Chem. Soc., 1991, 68, 245-249.

10. P. G. Baraldi, S. Manfredini, R. Romagnoli, L. Stevanato, A. N. Zaid, R. Manservigi, Nucleos. Nucleot. Nucleic Acid, 1998, 17, 2165-2171. DOI:10.1080/07328319808004307

11. K. M. El-Mahdy, A. M. El-Kazak, M. Abdel-Megid, M. Seada, O. Farouk, Acta Chim. Slov., 2016, 63, 18-25. DOI:10.17344/acsi.2015.1555

12. C. Párkányi, D. S. Schmidt, J. Heterocycl. Chem., 2000, 37, 725-729. DOI:10.1002/jhet.5570370409

13. K. Zaima, I. Koga, N. Iwasawa, T. Hosoya, Y. Hirasawa, T. Kaneda, I. S. Ismail, N. H. Lajis, H. Morita, J. Nat. Med., 2013, 67, 9-16. DOI:10.1007/s11418-012-0638-y

14. A. B. A. El-Gazzar, A. M. S. Youssef, M. M. Youssef, A. A. AbuHashem, F. A. Badria, Eur. J. Med. Chem. 2009, 44, 609-624. DOI:10.1016/j.ejmech.2008.03.022
15. F. Badria, M. Ameen, M. Akl, Z. Naturforschung, 2007, 62(9/10), 656-660. DOI:10.1515/znc-2007-9-1005

16. A. A. Fadda, A. El-Shafei, A. M. Khalil, T. A. E. Ameen, F. A. Badria, Bioorg. Med. Chem. 2009, 17, 5096-105. DOI:10.1016/j.bmc.2009.05.053

17. S. S. El-Morsy, A. A. Fadda, M. S. El-Houssini, Indian J. Chem. Soc. 1988, 65, 699-701.

18. A. A. Fadda, H. A. Etman, F. A. Amer, M. Barghout, K. S. Mohamed, J. Chem. Tech. \& Biotech. 1995, 62, 170-177. DOI: $10.1002 /$ jctb. 280620210

19. A. A. Fadda, A. M. El Defrawy, S. A. El-Hadidy, Amer. J. Org. Chem. 2012, 2, 87-96. DOI:10.5923/j.ajoc.20120204.03

20. K. Karrer, J. R. Rtjbini, Pharmacology, 1965, 13, 124-130. DOI1:0.1159/000135602

21. E. Lissi, B. Modak, R. Torres, J. Escobar, A. Urzua, Free Radical Res. 1999, 30, 471-477. DOI:10.1080/10715769900300511

\section{Povzetek}

S pomočjo 1,4-dihidro-4-okso-1,8-naftiridin-3-karbohidrazida (1) kot izhodne spojine smo pripravili serijo substituiranih 1,8-naftiridinskih derivatov ter jih uporabili kot citotoksične in antioksidativne spojine. Spojino 1 smo reagirali z različnimi reagenti in tako pripravili ustrezne 3-heteroarilkarbonil-1,8-naftiridinske derivative 3-19, ki smo jih testirali za in vitro citotoksičnost proti Ehrichovim ascitnim karcinomom in za antioksidativno aktivnost. Spojina 15 je pokazala najboljše citotoksične in antioksidativne lastnosti. 